AGNIESZKA BRYŁA-CRUZ ${ }^{1}$

DOI: 10.15290/CR.2019.26.3.01

Maria Curie-Skłodowska

University in Lublin, Poland

ORCID: 0000-0003-3256-3185

\title{
Communicative responsibility in non-native speech. Overcoming foreign accent in English in religious discourse
}

\begin{abstract}
Apart from evoking accent-based stereotypes, non-native speech has been found to pose threat to intelligibility and overburden listeners with additional cognitive load which may evoke their irritation (Johansson 1975; Kelly 2000; Munro 2003; Lippi-Green 2012; Moyer 2013). The paper discusses the notion of communicative responsibility defined as speaker's effort to overcome the undesirable consequences of foreign accent for the sake of efficient conveyance of relevant message. Five religious lectures (amounting to $5 \mathrm{hrs}$ of audio-visual material) delivered in Polish-accented English are discussed with respect to the speaker's non-native pronunciation and his morally motivated effort to convey the message precisely despite phonetically deviant speech. The shortcomings of non-native pronunciation are anticipated and targeted by preventive strategies, such as disambiguation, frequent repetition and use of emphatic stress to highlight the most relevant information, eliciting direct feedback from the listeners, monitoring their non-verbal responses, as well as the employment of enhancing devices, such as gestures.
\end{abstract}

Key words: communicative responsibility, foreign-accented speech, preventive strategies, intelligibility, religious discourse.

\section{Introduction}

The phenomenon of foreign accent as well as its implications for communication and functioning in society have attracted considerable attention from researchers working within different fields of study. This interdisciplinary interest is caused by the fact that (non-native) accent is not only an indicator of one's origin but also has been shown to evoke various racial, ethnic and religious stereotypes. The reason for this is that speakers in all communities "associate types of speech with types of people" (Williams 1970: 381) and "rely on language traits to judge others" (LippiGreen 2004: 291). There is ample empirical evidence which proves that due to its non-standardness foreign-accented speech tends to be stigmatized and its users downgraded on a wide array

1 Address for correspondence: ul. Kameralna 9/2, 20-864 Lublin, Poland. E-mails: agabryla@gmail .com 
of non-linguistic factors, e.g. competence, socio-economic status, personality traits (friendliness, kindness, reliability, overall intelligence) or even physical attractiveness (Lambert et al. 1960; Williams 1976; Lippi-Green 2012). This leads to "linguistic profiling", an auditory equivalent to racial profiling (Baugh 2003), manifesting itself in discriminatory practices in employment or educational areas as well as media portrayals (Lippi-Green 1997; Munro 2003).

Due to expanding awareness regarding the undesirable implications of sounding non-native, many immigrants enroll in accent reduction classes to increase their chances in e.g., a job interview and enhance assimilation in the target society. Similarly, many politicians strive to improve their pronunciation and enunciation in English (be it their L1 or L2) in order to deliver their political message in the most persuasive way and avoid accent-based stigmatization. In both cases overcoming foreign accent is propelled by personal gain (prestige, image, social and financial benefits) so it can be viewed as speaker-oriented.

The present paper provides a preliminary insight into a so far practically unexplored interface of non-native speech and communicative responsibility. There are some spheres of human activity (aviation, the army) where accented speech may have particularly grave consequences for successful communication affecting not only an individual's image and career opportunities, but having impact on the lives of a large group of people (Strother 1999; Woods 2006; Erwin 2005). It is due to the fact that even though intelligibility depends on multiple factors related to the speaker, the listener and the context (Brown 1991; Wright 2003), pronunciation has been shown to play a pivotal role in how effectively meaning is conveyed (Jenkins 2000; Field 2005).

Despite a vast body of theoretical and empirical studies on the nature and perception of foreignaccented speech, none of them has focused on the notion of responsibility. In this paper, communicative responsibility refers to attempts of overcoming foreign accent which are not speakeroriented but addressee-oriented. Religious discourse in foreign-accented English has received no attention from phoneticians and it is also in this area that the links between pronunciation and listener-oriented responsibility can be observed. In what follows five religious lectures delivered in Polish-accented English will be discussed with respect to the speaker's non-native pronunciation and his morally motivated effort to convey the message precisely despite phonetically deviant speech. It will be argued that the speaker feels responsible for the listeners' comprehension because firstly, he deems the transmitted content vitally important, and secondly, he recognizes that his foreign accent may impair intelligibility. Just like in aviation or the army, being understood properly can be a matter of life and death, in this case in its spiritual dimension (at least from the speaker's perspective).

\section{Communicative responsibility: content - form interface}

Responsibility is a concept that is recurrent in everyday life and, similarly to foreign accent, has been explored by researchers of various disciplines (philosophers, psychologists, sociologists, theologists and lawyers). While most language users intuitively know what the term implies and are able to enumerate responsibility-related notions (e.g. liability, accountability, duty, obligation, 
blame, punishment), no exact, comprehensive and universally accepted definition of the construct itself exists (Auhagen \& Bierhoff 2001). This is because it is a complex social phenomenon which is inherently multi-faceted. Researchers tend to emphasize different aspects of responsibility depending on their particular topic and the adopted approach. One of the most positive connotations of the term is "ethical and moral values, or caring" (Auhagen \& Bierhoff 2001: 3).

Communicative responsibility is viewed in this paper as the speaker's morally motivated concern for his listeners' comprehension, which manifests itself in the speaker's attempts to overcome the negative consequences of his foreign-accented English. Nowadays it is often argued that since communication is a two way process, responsibility for effective interaction between nonnative and native speakers should encompass not only the former as skilled speakers but also the latter as "active, responsive and unprejudiced listeners" (Derwing et al. 2014: 76). It is even positioned that placing the whole burden of communication on non-native speakers is unethical and monolingual speakers of English should be trained to understand accented speech and be encouraged to change their attitudes, i.e. become more empathetic and less anxious to interact with nonnative speakers (Derwing et al. 2014). This stands in contrast with what Bansal (1969: 15) advised almost five decades ago in his classic research on the intelligibility of Indian English, namely "to be intelligible the speaker must articulate his sounds clearly, so that the hearer does not have to stop and think what word was meant."

\section{Method}

The corpus for qualitative observations and discussion is constituted by five religious lectures providing approximately 5 hours of audio-visual diagnostic material delivered by Father Piotr Glas in Polish-accented English. They were recorded live and posted on a YouTube channel RCS TV International, which is one of countless examples of the religious appropriation of the new media technology for spreading faith. With the advancement of the internet and new ways of communication, the potential of seemingly secular practices to serve a religious role in everyday life has been recognized quickly and dominant media technologies have been embraced as a means of both preaching and practising beliefs (Campbell 2013). As a result, "religion of every kind, big and small, old and new, mainstream and more exotic is present online, and in great abundance" (Dawson 2005: 15).

The analysis was carried out auditorily and its multimodal character is reflected in the fact that apart from sound also the speaker's body language was taken into consideration.

\subsection{The speaker's perception of the content of his preaching}

The speaker discussed in what follows, Fr. Peter Glas, is a Catholic priest and exorcist of Polish origin who has resided and worked in England (Manchester, Lancaster, Southampton Bournemouth, Jersey, Portsmouth and Reading) since 1991. He uses English on a daily basis to communicate with English native speakers in England and occasionally in the USA and Australia. It is this language that is his main tool in the service. His English is marked with Polish accent, 
which is to be expected as he learnt it in his adulthood far beyond a sensitive age deemed necessary for acquiring native-like pronunciation. He does not conceal the fact that he arrived in England with very basic command of English (in one of his lectures he refers to his English at that time as "was very limited," "school English"), which not only was insufficient for effective daily communication, but also generated embarrassment due to serious misunderstandings.

The speaker shows higher than average awareness of his foreign accent, which becomes apparent in his comments "Can you understand me? Cause my accent is not your accent," "This will be on the video also. Hopefully people can understand my accent." Rather than expecting his English native listeners to accommodate to him, he exerts effort to reduce the load generated by his accented speech. He is convinced of the relevance of the message he sets out to convey, on the one hand, and recognizes that his accented speech may pose a hindrance to carrying out this task satisfactorily, on the other.

Certainly, it can be positioned that other public speakers (e.g. politicians or activists) also strongly believe in their message and will try to make themselves properly understood when delivering it. Yet, preaching is distinct from any other form of public speaking because of its content which is perceived as a message from God. Lischner (2002: 47) goes as far as to conclude that "(n)o other modern public speaker does what the preacher tries to do" and thus sets religious discourse apart from the rest of public speech acts, with preaching viewed as primarily "an act of faith" (2002: 49). According to Stott (2017), a sermon typically begins with the announcement of one's text, which declares that the Christian preacher accepts his "responsibility to expound God's Word," rather than express his own opinions (2017: 190). In the Augustinian spirit upon the preacher rests the primordial duty to be "the defender of right faith and the enemy of error" (Resner 1999: 40). In other words, the preacher's primary service is yielded not to earthly institutions, political movements or ideologies, but he is called to be a servant of the divine truth and his mission is to proclaim the gospel and save people's lives from spiritual death. Importantly, the preacher's authority does not derive from his education, professional experience, rank or power but from his encounter with God while engaging with the Scripture (Johnson 2015). This transforms the preacher into a witness and he "shapes the words and patterns of the sermon to correspond to the truth the preacher has heard and seen" (Johnson 2015: 38).

Father Glas frequently refers to himself as a witness and views his preaching as a testimony, e.g. "I want to witness to you," "I want to give you an idea, a picture," "I want to open your eyes," "I do my best to open people's hearts," "I'm speaking to you freely. The truth. And you share this truth with other people." He experiences a particularly strong sense of mission attached to his priesthood and repeatedly stresses the fact that he "feels responsible for people's souls," and "saving people" and wants to bear testimony of what he has witnessed: "I'd like to be with you, not as a preacher, but share with you my testimony, my knowledge, my experience." This identity has ramifications for the preacher's communication on semantic, phonetic and non-verbal levels, which is in line with the conviction that "a witness is a translator who is required to find the right words, images and form" (Johnson 2014: 117). 
The speaker views his preaching activity as a battle with evil forces and uses a war / battle metaphor to frame everyday spiritual experiences of human beings. This is apparent both in the titles of his lectures as well as the imagery he employs to explain the basic mechanisms of demonic activity, e.g. spiritual warfare, spiritual defense, strategy, attack, weapon, armour, fight, combat, war, battlefield, fortress, stronghold, headquarters, castle, perpetrator, enemy, general, marshall, missile, grenade, victory, taking the land, occupying etc. Against this backdrop, his own role and moral obligation is to prepare people for the battle, in other words to raise their awareness of spiritual reality where demonic activity manifests itself, e.g. "I was ordained as well to fight with the powers of darkness that do exist, that are real, that are powerful, not more powerful than God, but they are powerful because we are ignorant." In his view, this is an unpopular and neglected issue even within the Church and nowadays the existence of embodied evil is completely denied not only by lay people but, more alarmingly, even by some of the clergy ("How many of us do fight? How many of us are ready, prepared, trained? We are not ready for the battle.").

It can be concluded that the speaker perceives the content of his preaching as very important and not just to himself but to every single person listening to him at the moment of speaking and also to all those who can familiarize themselves with his message indirectly.

\subsection{The speaker's perception of his accented speech}

According to Flege (1988: 229), "foreign accent is a phenomenological experience of listeners that is derived from detectable acoustic (and perhaps visual) differences between native and non-native speakers in the pronunciation of sounds and other speech units". As a result, on detecting a foreign accent listeners are able to recognize that the interlocutor is not "a fellow native speaker" (Flege \& Southwood 1999: 336). By making references to his foreign accent Fr. Glas acknowledges his position of an outsider. Yet, he identifies with the listeners by showing genuine concern to be understood as well as involvement and solidarity (he refers to them as "friends"). This is congruent with what is advocated by Roembke (2000: 84), namely, that "the goal of the missionary is to become as much an insider as is necessary to be credible" and this does not have to amount to "imitation or the sentimental attempt to 'go native'". Imitation can be counterproductive and result in contempt, which is the most significant obstacle to mutual understanding (Roembke 2000: 84).

Fr. Glas displays a high level of awareness that his speech is marked with a foreign accent and recognizes its potential threat to communication. Indeed, obstructed intelligibility is often the first shortcoming of foreign accent and "foreign-accented speakers tend to be evaluated more negatively than native-accented speakers simply because they are harder to understand" (Dragojevic \& Giles 2016: 16). While semantic, grammatical and pragmatic context can facilitate comprehension and eliminate ambiguities (Brown 1991), it should not be assumed that it can always compensate for phonetic inaccuracies. Context itself depends on how much of the previous input has been properly decoded by the listener (Field 2005). Moreover, sometimes context may allow for two or more phonetically similar words or phrases. Anecdotal evidence of intelligibility breakdown because of foreign-accented English can be observed in one of Dalai Lama's spiritual talks. When 
referring to differences in religion and race he said "I think we should forget it." People burst into enthusiastic laughter, some of them started whistling or applauding and others had vague expressions on their faces. The Tibetan monk was confused because he repeated the same idea a few times and the listeners' reaction felt inadequate. Because of inappropriately placed word-stress and segmental distortions "forget it" was understood as "fuck it" (both f-words matched the context but, needless to say, only one was suitable in terms of register).

Incorrect pronunciation may be "funny" or "cute" at the outset but will become tiresome with the passing of time and may even undermine credibility of the mission / church in the long run (Roembke 2000: 73). According to Johansson (1975), one of the by-products of foreign accent is diverting the listener's attention from the message towards the form. In the literature it has been labeled "irritation" (Ludwig 1982: 275) and can range from unobtrusive awareness of the speaker's erroneous pronunciation to constant focus on the code which overwhelms the conveyed message and impedes successful discernment of the meaning. Learners are not always cognizant of the fact that "the way they speak is resulting in difficulty, irritation or misunderstanding for the listener" (Kenworthy 1987: 8) and, consequently, do not pay proper attention to their pronunciation. Fr. Glas, however, is aware of additional load placed upon his listeners due to his foreign accent, which is apparent when he asks "Should I finish now? Are you tired?"

Summing up, the speaker displays a particularly strong belief in his service to the congregation and is genuinely concerned about being properly understood despite his foreign accent. As a result, he assumes responsibility for transmitting the message and employs strategies which are meant to safeguard intelligibility and reduce the listeners' effort invested in processing his speech.

\subsection{Overcoming fallouts of accented speech}

McRoy and Hirst (1995) argue that even though interlocutors may not always recognize intelligibility breakdown when it occurs, they are aware that a misunderstanding can occur. When a problem in comprehension is anticipated, the speaker can resort to a strategy of prevention (Clark 1994), in other words, a mechanism to restrain misunderstanding or non-understanding. In the analysed data, the shortcomings of foreign-accented speech are anticipated and targeted by preventive strategies, such as disambiguation, frequent repetition and use of contrastive stress to highlight the most relevant information, eliciting feedback from the listeners, observing their nonverbal responses as well as enhancing devices, such as gestures (hand gestures, mimicry), whole body movements and extra-linguistic sounds. All these are employed to aid comprehension and in the case of gestures to "enhance the communicative signal" (De Ruiter 2017: 72).

Fr. Glas is alert to lexical factors (or "neighbourhood density" as termed by Luce \& Pisoni 1998) which may diminish the probability of a word being accurately identified. Word recognition is better for words from sparse neighbourhoods due to smaller competition between phonetically similar words (Walley 2007). Fr. Glas anticipates a potential confusion of the intended word soul /soul/ with a phonetically similar one salt/so:lt/ and, therefore, deploys a preventive strategy of 
disambiguation by means of contrasting the target item with a possibly disruptive one: "soul, not salt, you know, soul". This is accompanied with clear enunciation and slowed down rate of speech.

He correctly uses prominence (increased intensity, pitch and duration) in order to highlight the most relevant information within a thought unit. Examples of emphatic stress include the following: "Facebook, twitter. You have TWO THOUSAND friends. You have two thousand FRIENDS?", "People ARE gifted with discernment, but very often you have to be careful," "What's the DEEDS?" "Five MILLION websites your children can access."

Similarly, repetitions serve the purpose of drawing the listeners' attention to the key part(s) of the sentence. Enumerating is always performed with the use of fingers and raised hand, usually repeated, e.g.

"What is the unholy trinity? Big three guys: rejection, abandonment and fear."

"They attack your emotions, memories, feelings, traumas."

"What really kept me to do this ministry, there were three things, my friends. First was the faith, the second is the fighting spirit, and the third one was the joy in the Holy Spirit."

"We need to pray for three things: knowledge, prudence and discernment."

Even though Fr. Glas's preaching lectures are expository in nature, he often interrupts his discourse to make sure that the message is accessible to the listeners. To this end he addresses his listeners directly, e.g.

- "Are you following me?"

- "Can you understand me clearly?"

- "Are you OK?"

- "Is it all right?"

- "Is that helpful what I'm saying?"

- "Do you agree with me?"

On such occasions he often mentions his foreign accent as a potential obstacle to effective communication, e.g. "Do you understand me? I think I speak so fast with this foreign accent," "Can you understand me? Cause my accent is not your accent."

Apart from explicit ways of checking understanding, he maintains eye contact and monitors the addressees' verbal and non-verbal responses. He seems to be aware of the fact that competent speakers should "read" their audience and that "good powers of observation are helpful to detect whether a misunderstanding has been created" (Roembke 2000: 125).

Substantial evidence from a range of studies points to the fact that speakers use gestures as an element of their effort to communicate (Kendon 2004). As argued by McNeill (2016), speech and gesture are manifestations of thought and "the greater the felt departure of thought from the immediate context, the more likely its materialization in a gesture". Consequently, the extent to which gestures are elaborated depends on the relevance of materialization of the existence of the thought (McNeill 2016: 15).

Fr. Glas employs a very wide range of speech-related hand gestures (deictic and imagistic) as well as mimicry, head movements and gaze shifts. Apparently, the motivation beyond this 
practice is to render the complex and abstract ideas more concrete. In the analysed lectures many gestures are repetitive. They constitute a certain system (code) and reflect the speaker's mind in the same way as words; they are "an imagistic version of what is being spoken" (Church et al. 2017). Imagistic gestures can be divided into iconic, i.e. representing a concrete action or object and metaphoric, i.e. standing for some abstract concept (Kendon 2004). The discourse is produced by words and gestures and, thus, just like Fr. Glas's speech abounds in battle-related terminology, his gestures that reflect the same notions and body movements which denote punching, boxing, hitting, attacking, occupying are recurrent. Even though they display an image which is concrete in the real world, their essence is metaphorical because the image of fight is used metaphorically in the discourse. Below, some examples are provided:

"I cannot just fight blindly, you know" - extended arms with clenched fists move forward and backward as in boxing.

"I was a fighter, you know. And I'm still a fighter." - the clenched fist makes a punching gesture.

"Demons' priority is to bombard us non-stop" / "I received lots of hits, you know" - the clenched fist hits against the spread palm repeatedly.

"And the devil knows that and attacks" - the clenched fist moves forward as in a punch.

"That's the same that demons do. They take the land and occupy it." - both hands make a plunging gesture.

"That's why some people give up" - both arms held upwards in an open-handed posture as in surrender.

Sometimes the speaker uses metaphoric gestures to explain some notions or make them more vivid,

e.g. "It's easy, really, to be re-diverted" - makes a winding gesture with one arm.

"They create soul ties. Take a string and there is a hook on one side and on the other side" - raises his arms above his head and draws an invisible line in the air and marks each end of it.

Iconic gestures are also ubiquitous. They reflect a concrete idea from the discourse, e.g. "a big smile on his face" - the index finger draws an invisible smile in the air close to the mouth,

"you know, computers" - fingers imitate typing movements.

In addition to the above mentioned imagistic gestures, deictic gestures also appear frequently. These pointing gestures refer to either concrete entities and locations or abstract spaces relating to an idea or concept (McNeill 1992),

e.g. "Where is the battlefield? The battlefield's in my mind" / "This is my mind. This is the biggest battlefield." - puts his spread palm on the top of the head. 
"Which battle is the worst? Within us." - points with index fingers to his chest.

"You must forgive not from your mind, brain. Forgive from the place where the wound is" the index finger points to the top of the head first and then to the chest

"What is underneath?" - the index finger goes down.

"It doesn't matter if you wear a collar" - points to his own collar.

Body movements and mimicry are sometimes accompanied with extralinguistic sounds,

e.g. "I feel sometimes like a dentist, you know the nerve, I touch the nerve" - puts his hand close to the jaw and imitates the sound of a dental drill and shakes his head

"And then he jumps and starts screaming aaaaaa!" - moves his whole body up as in a small jump and shakes his head slightly.

It should be noted that even though Fr. Glas uses gestures in similar talks delivered in his native language, they are much more elaborate and frequent when his means of communication is English. This is in line with observations reported in the literature, namely that learners produce more gestures when they express themselves in their L2 than when they speak their L1 (Gullberg 2008: 195). Fr. Glas goes to more effort when conveying his message in English and sometimes uses gestures in an intentional attempt to prevent undesirable homophony, e.g. in the above mentioned example of soul - salt he makes sure also by non-verbal means that the target item is properly decoded, i.e. he points to his chest simultaneously saying "soul". It could be thus argued that not only do gestures constitute an aid to comprehension, but also in a way compensate for self-perceived imperfections of foreign-accented speech. This happens because unlike learners' speech, gestures are not ambiguous and their "physical and spatial properties make them ideally suited for disambiguation" (Gullberg 2008: 198).

According to previous research, gestures are used by non-native speakers as a communicative device to compensate for lexical, grammar or fluency problems and also as a means to elicit help from interlocutors (Gullberg 1998). It must be noted that Fr. Glas has a very good command of English in terms of grammar, vocabulary and idiomatic expressions. Therefore, his use of gestures as a compensatory strategy would be limited to disambiguating what, in his own view, he cannot distinguish clearly enough in speech.

The phrase "in his own view" in the previous sentence deserves some comment. As explained at the beginning of section 2., communicative responsibility is about the speaker's awareness of his phonetic deficiencies and his effort to overcome them because the message is of vital importance and communication breakdown has grave consequences. Interestingly, Fr. Glas pronounces both words from the above example (soul - salt) properly; he does not monophthongize the vowel in soul, which is a typical error made by Polish speakers (*/sol/). If he had done so, then both words would have been pronounced with a monophthong and the probability of confusion would have risen dramatically. In this case, however, disambiguation seems not that necessary 
and the fact that Fr. Glas remains careful intensifies his responsibility even more. At this point it is worthwhile to discuss the speaker's foreign accent to determine if his own intuitive evaluation and actual phonetic properties of his speech overlap in terms of the extent to which they may impair intelligibility.

\subsection{Phonetic properties of the speaker's non-native pronunciation}

It should be noted that the following characterization of the speaker's non-native pronunciation is by no means exhaustive. Its main aim is to determine the presence / absence of those phonetic features of Polish English which English native speakers evaluated most harshly in empirical studies in terms of accentedness, irritation and intelligibility. The analysis was performed auditorily.

Perceptual studies on Polish-accented English point to spelling-induced mispronunciations (rather than single segmental substitutions) as one of the main obstacles to intelligibility in communication with English native speakers (Szpyra-Kozłowska 2013; Bryła-Cruz 2016). Such errors tend to distort significantly the whole word, more often than not, rendering it virtually unrecognizable, e.g. purpose /pur'pous/, lettuce/'letjus/. Shifted word-stress has also been found to interfere with comprehension (Field 2005) and many researchers argue that "the stress pattern of the word is an important part of its identity for the native speaker" (Kenworthy 1996: 112). The speech samples which constitute the focus of the present study are, on the whole, correct with respect to word-stress placement even in those items which Polish learners distort on a regular basis, e.g. ${ }^{\star}$ COMputer, ${ }^{\star}$ Exam, ${ }^{\star}$ DEvelopment. Similarly, only single instances of spelling-based errors have been spotted in the analysed data, i.e. possession /po'se $\int \mathrm{n} /$, focus /'fokus/, authority /au'toritiI/, trauma/'traumə/, frustration /frus'treISn/, discover /dis'kəvə/, gluttony/'glutoni/. Interestingly, Fr. Glas properly articulates words which are listed among 600 words commonly (and notoriously) mispronounced by Polish (even advanced) learners of English (Sobkowiak 1996), e.g. area, determined, bullet, colonel, worship, biscuit.

Another area of English phonology problematic for Polish learners is vowel inventory. Due to a considerable discrepancy both in vowel quality and quantity, Poles tend to neutralize many contrasts and produce off-target vocalic sounds. This can hamper intelligibility, particularly where there is a possibility of a minimal pair, e.g. live vs. leave. Fr. Glas realizes proper distinctions between /I/ vs. /ii:/ feel vs. fill); /æ/ vs. / / (cat vs. cut), /o/ vs. /əu/ (rob vs. robe). He does not maintain a proper contrast in length or quality in /Q/ vs. /O:/ and /U/ vs. / u: / It can be concluded (even though with due caution) that in this respect his English is unlikely to pose comprehension problems as perceptual studies on Polish-accented English have not determined back high and back medium vowels as indispensable for intelligibility (Bryła-Cruz 2016).

Phonetic priorities for Polish speakers encompass properly articulated velar angma, i.e. without the accompanying plosive in words like singer */singə/ or bring*/brink/ and the interdental fricatives, i.e. not substituted with plosives or fricatives in words like three*/fri:/ or this */vis/. These mispronunciations may be disruptive to comprehension, but the main reason for their inclusion in error gravity lists is strengthening the impression of foreign accent (Szpyra-Kozłowska 2013; 
Bryła-Cruz 2016). Fr. Glas inserts / k, g/ after / y/, e.g. healing / hi:lıyk/, strong / stroyk/, singers /singes/ and substitutes $/ \theta /$ and /ठ/ with /t/ and /v/, respectively, e.g. thousand /tavzont/, mother / $\mathrm{m} \Lambda \mathrm{va} /$. These distortions are consistent throughout his speech and intensify the impression of non-nativeness and may trigger the native listeners' annoyance (Bryła-Cruz 2016). On the other hand, the context (lexical, grammatical and pragmatic) is usually helpful and prevents ambiguity, e.g. "he was strong (/stroyk/) enough to defeat (...)", "how many young /jıyk/ people, youths, teenagers (...)".

As discussed in section 2.2., Fr. Glas is well aware of speaking English with a foreign-accent. It is beyond the scope of the present paper to investigate to what extent he is also aware of the fact that his speech exhibits many properties of English native pronunciation. Interestingly, these phonetic features are not acquired easily in guided instruction even by advanced Polish learners of English, which the present author can observe during her pronunciation courses conducted with the students of the English department at a Polish university.

One of the most challenging aspects of English phonetics for Polish speakers is aspiration (a delay in the onset of voicing, VOT) of stressed fortis plosives. This feature is an important cue for English native speakers who would ascribe the main difference between the initial stops in pet and bet to the force of articulation rather than the action of the vocal folds (the lack of aspiration would lead to interpreting / $\mathrm{p} /$ as its lenis counterpart /b/). P. Glas employs aspiration correctly whenever $/ \mathrm{p}, \mathrm{t}, \mathrm{k} /$ are initial in stressed syllables, e.g. $\mathrm{p}^{\mathrm{h}}$ astor, pret $^{\mathrm{h}} \mathrm{end}$, $\mathrm{c}^{\mathrm{h}}$ onflict. Moreover, his speech in Polish also exhibits longer VOT values for voiceless plosives, which shows that with respect to aspiration, his native language has become English-accented and not the opposite.

Other native-like features, problematic to Polish learners and present in Fr. Glas's English, include syllabicity of sonorants e.g. problem / 'problm/, satan /'seitn/, mission /' $\mathrm{m} 1 \mathrm{j} / \mathrm{n}$, religion /ri'lidzn/. The dark / $\$$ / is not substituted by clear / / (as is commonly done by Polish learners), e.g. devil /'dev11/, scandal /'skænd1/, miserable /'mizorbł/, battle /'bætł/, hell / heł/. It should be added that improper realizations of these consonantal features intensify the impression of foreign accent and can hamper intelligibility (Bryła-Cruz 2016). Still, Fr. Glas uses them correctly, even if sometimes inconsistently.

Another property of Fr. Glas's accent is non-rhoticity, i.e. pronouncing / $\mathrm{r} /$ only before a vowel. Generally, Polish speakers prefer a rhotic version of English because of greater spelling-sound correspondence. The omnipresence of American English in the media (music, film, advertising) also contributes to this heavy tendency. The fact that Fr. Glas suppresses / r/ word-finally and before a consonant shows that his speech is clearly modeled on British English, and this variety is more difficult for Poles as far as the distribution of rhotic is concerned.

Two other features that pose a considerable challenge to Polish speakers of English but still occur in Fr. Glas's speech are reducing vowels to schwa in an unstressed syllable, e.g. important /1m'po:tənt/, darkness /'da:kn1s/, desperate /'desprit/ and no audible release in stop clusters (releasing the first plosive together with the following one), e.g. chapter, kept, protected. Last but not least, it should be mentioned that Fr. Glas employs consistently selected phenomena of connected 
speech in native-like fashion, i.e. linking "r" e.g. unaware of it / $\Lambda$ nə'weər əv $1 \mathrm{t} /$, pick her up /'p1k hər' $\Lambda \mathrm{p} /$ and yod-coalescence, e.g. put you / 'potfo/, cares about you / keəz ə'bavtfo/, as you know /azu 'nov/.

It could be concluded that Fr. Glas is rather critical with the evaluation of his own non-native speech. Even though it cannot be denied that his English is foreign-accented (particularly in terms of prosody, i.e. intonation and rhythm) and he definitely would not pass for a native speaker, his phonetic competence is, on the whole, better than that of average Polish learners of English. It lacks typical hallmarks of Polish accent in English, e.g. spelling-induced errors, which impinge most upon intelligibility, and are the most annoying to English native speakers (Szpyra-Kozłowska 2013; Bryła-Cruz 2016). Moreover, his speech has distinct traces of standard British accent. The fact that Fr. Glas is alert and employs a wide range of preventive strategies to overcome phonetic imperfections demonstrates further his communicative responsibility. He does not rely on such strategies to compensate for insufficient time or effort invested in improving his foreign accent. Quite to the contrary, as the above analysis reveals, he must have taken charge of his accent during language learning. As Moyer (2013: 58) ascertains, "not everyone wants or tries to sound native, but without that drive it is difficult to overcome the features that mark one as a non-native speaker".

One could argue that Fr. Glas has acquired some properties of British English effortlessly over his long immigrant experience (27 years). Yet, as reported in previous studies, length of residence (LoR) as such is not a reliable predictor of phonetic success as it does not necessarily equal ample exposure to the target language or meaningful interaction with its speakers (Asher \& García 1969; Oyama 1976; Thompson 1991). In other words, it is definitely not the amount of time spent in the host country that matters for adult language learners, but "whether they have sufficient opportunity and inclination to acquire native-like mastery" (Moyer 2013: 73).

Fr. Glas represents an individual who has recognized the fact that his extended residence confers benefits to his phonetic attainment and has taken responsibility for improving his interlanguage accent. This last statement is corroborated by an interview the present author conducted with the preacher in which he admits: “One cannot change one's own accent but it's necessary to work on it to speak with the possibly best pronunciation". Fr. Glas highlights the fact that upon his arrival in England he took private lessons and his aim was not just to achieve mere communicativeness and be able to get his message across in whatever way, but to have clear enunciation. As a result, he expected and appreciated explicit correction of phonetic mistakes from his teachers.

\section{Concluding remarks}

Apart from evoking accent-based stereotypes, non-native speech has been found to pose threat to intelligibility and overburden listeners with an additional cognitive load which may evoke their irritation. The paper discussed the notion of communicative responsibility defined as speaker's effort to overcome the undesirable consequences of foreign accent for the sake of the efficient conveyance of the relevant message. 
The analysis of five religious lectures delivered in Polish-accented English revealed that the speaker is aware of his phonetically imperfect means of communication and assumes responsibility for potential difficulties it may trigger. His concern for diminishing phonetic deficiencies is addressee-oriented, unlike in most accent reduction courses whose primary focus is on removing the traces of non-native speech in order to enhance one's image, avoid stigmatization and pursue personal or professional goals. The speaker in this study anticipates problems which may arise due to his accent and employs strategies to prevent misunderstanding or non-understanding. Disambiguation is used to counteract undesirable homophony of two phonetically similar words which the speaker is afraid to mispronounce. Frequent repetition and prominence (increased intensity, pitch and duration) highlights the most relevant information. The speaker also resorts to direct and indirect interaction with the listeners in order to check whether he is supposed to repeat, clarify or reformulate what has just been said. Last but not least, he enhances his discourse with ample gesticulation which renders abstract ideas more concrete and, thereby, the broader context, which plays an indispensable role in comprehension, becomes more accessible.

Communicative responsibility of the speaker is apparent not only in what he does to overcome his foreign accent at the moment of delivering his discourse, but also is manifested in time and effort invested in pronunciation training prior to the speech act. Phonetic properties of his English provide further evidence of linguistically responsible behaviour, since his foreign accent is devoid of many Polish English features evaluated harshly by English native speakers in perceptual studies. Moreover, his speech is not an outcome of random attempts to sound correct, but displays distinct properties of native-like British accent, which cannot be attributed to effortless and unintentional acquisition.

It is thought-provoking that this type of profound phonetic concern is showed by a person whose profession is not linked to L2 instruction. A great many English teachers in different countries around the world seem unaware of the undesirable effects of foreign accent on communication and fail to encourage their learners to consciously practise pronunciation in and out of the classroom. Actually, phonetic training has been neglected so lamentably that labels like "the orphan" (Gilbert 2010) or "Cinderella" (Kelly 1969; Celce-Murcia et al. 1996) of English language teaching have been ascribed to it. Communicative responsibility is not a local phenomenon (restricted to individuals as exemplified here), but also can be viewed more globally and further research should focus on how to foster responsibility for pronunciation teaching and learning, particularly among those language educators who deal with children and train future teachers. The present paper demonstrated that intelligible and not heavily accented speech is relevant for and appreciated by people involved in jobs unrelated to pedagogical contexts, e.g. religious service. 


\section{References}

Asher, J. \& García, R. 1969. The optimal age to learn a foreign language. Modern Language Teacher 53: 334-341.

Auhagen, A.E. \& Bierhoff, H. (eds.). 2001. Responsibility: The Many Faces of a Social Phenomenon. London: Routledge.

Bansal, R. K. 1969. The Intelligibility of Indian English: Measurements of the Intelligibility of Connected Speech, and Sentence and Word Material, presented to Listeners of Different Nationalities. Hyderabad: Central Institute of English.

Baugh, J. 2003. Linguistic profiling. In: S. Makoni, G. Smitherman, A. Ball \& A. Spears (eds.), Black Linguistics: Language, Society and Politics in Africa and the Americas, 155-168. London: Routledge.

Brown, A. 1991. Pronunciation Models. Singapore: Singapore University Press.

Bryła-Cruz, A. 2016. Foreign Accent Perception: Polish English in the British Ears. Newcastle upon Tyne: Cambridge Scholars Publishing.

Campbell, H. A. (ed.). 2013. Digital Religion: Understanding Religious Practice in New Media Worlds. London/New York: Routledge.

Celce-Murcia, M., Brinton, D. M. \& Goodwin, J. M. 1994. Teaching Pronunciation: a Reference for Teachers of English of Speakers of other Languages. Cambridge: Cambridge University Press.

Church, R. Breckinridge, Alibali, M.W. \& Kelly, S. D. 2017. Understanding gesture: Description, mechanism and function. In: R. B. Church, M. W. Alibali \& S. D. Kelly (eds.), Why Gesture? How the Hands Function in Speaking, Thinking and Communicating (Gesture Studies 7), 3-10. Amsterdam/Philadelphia: John Benjamins Publishing Company.

Clark, H. H. 1994. Managing problems in speaking. Speech Communication 15: 243-250.

Dawson, L. L. 2005. The mediation of religious experience in cyberspace. In: M. T. H2jsgaard \& M. Warburg (eds.), Religion and Cyberspace, 15-37. New York/London: Routledge.

De Ruiter, J. P. 2017. Asymmetric redundancy of gesture and speech. In: R. B. Church, M. W. Alibali \& S. D. Kelly (eds.), Why Gesture? How the Hands Function in Speaking, Thinking and Communicating (Gesture Studies 7), 59-75. Amsterdam/Philadelphia: John Benjamins Publishing Company.

Derwing, T., Fraser, H., Kang, O., Thomson, R. 2014. L2 Accents and ethics. Issues that merit Attention. In: A. Mahboob \& L. Barratt (eds.), Englishes in Multilingual Contexts: Language Variation and Education, 63-80. New York/London: Springer.

Dragojevic, M. \& H. Giles. 2016. I don't like you because you're hard to understand. Human Communication Research 42 (3): 396-420.

Erwin, S. I. 2005. Language Barriers Hinder Multinational Operations. National Defense (90). http://www.nationaldefensemagazine.org/articles/2005/7/1/2005july-language-barriers-hinder-multinational-operations, retrieved March, 2017.

Field, J. 2005. Intelligibility and the listener: The role of lexical stress. TESOL Quarterly 39 (3): 399423. 
Flege, J. E. 1988. The production and perception of foreign language speech sounds. In: H. Winitz (ed.). Human Communication and its Disorders. A Review, 224-401. Norwood, NJ: Ablex.

Flege, J. E. \& Southwood, H. 1999. Scaling foreign accent: direct magnitude estimation versus internal scaling. Clinical Linguistics and Phonetics 13 (5): 335-349.

Gilbert, J. B. 2010. Pronunciation as orphan: What can be done? Speak Out! 43: 3-7.

Gullberg, M. 1998. Gesture as a Communication Strategy in Second Language Discourse. A Study of Learners of French and Swedish. Lund: Lund University Press.

Gullberg, Marianne. 2008. A helping hand? Gestures, L2 learners, and grammar. In: S. G. McCafferty \& G. Stam (eds.), 185-210. Gesture: Second Language Acquisition and Classroom Research. New York/London: Routledge.

Johansson, S. 1978. Studies of Error Gravity: Native Reactions to Errors Produced by Swedish Learners of English. Göteborg, Sweden: Acta Universitatis Gothoburgensis.

Johnson, T. D. 2014. The Preacher as Liturgical Artist. Metaphor, Identity and the Vicarious Humanity of Christ. Cascade Books: Oregon.

Johnson, P. W. T. 2015. The Mission of Preaching: Equipping the Community for Faithful Witness. Downers Grove: InterVarsity Press.

Kelly, G. 2000. How to Teach Pronunciation. Harlow: Longman.

Kendon, A. 2004. Gesture: Visible Action as Utterance. Cambridge: Cambridge University Press.

Lambert, W. E., Hodgson, R. C., Gardner R. C. \& Fillenbaum, S. 1960. Evaluational reactions to spoken English. Journal of Abnormal and Social Psychology 60: 44-51.

Lenneberg, E. 1967. Biological Foundations of Language. New York: John Wiley.

Lippi-Green, R. 1997. English with an Accent. Language, Ideology, and Discrimination in the United States. Devon: Biddles Ltd.

Lippi-Green, R. 2004. Language ideology and language prejudice. In: E. Finegan \& J. R. Rickford (eds.), Language in the USA: Themes for Twenty-first Century, 289-304. Cambridge: Cambridge University Press.

Lischner, R. 2002. The Company of Preachers: Wisdom on Preaching, Augustine to the Present. Grand Rapids: Wm. B. Eerdmans Publishing Co.

Luce, P. A. \& Pisoni, D. B. 1998. Recognizing spoken words: the neighbourhood activation model. Ear Hear 19 (1): 1-36.

McRoy, S. W. \& Hirst, G. 1995. The repair of speech act misunderstandings by abductive inference. Computational Linguistics 21 (4): 435-478.

McNeill, D. 1992. Hand and Mind: What Gestures Reveal about Thought. Chicago: The University of Chicago Press.

Moyer, E. 2013. Foreign Accent: The Phenomenon of Non-Native Speech. Cambridge: Cambridge University Press.

Munro, M. J. 2003. A primer on accent discrimination in the Canadian context. TESL Canada Journal 20 (2): 38-51. 
Oyama, S. 1976. A sensitive period in the acquisition of a non-native phonological system. Journal of Psycholinguistic Research 5: 261-285.

Penfield, W. \& Roberts, L. 1966. Speech and Brain Mechanisms. New York: Atheneum.

Resner, A. 1999. Preacher and Cross: Person and Message in Theology and Rhetoric. Grand Rapids, Michigan: Eerdman.

Roembke, L. 2000. Building Credible Multicultural Teams. Pasadena (CA): William Carey Library.

Sapon, S. 1952. An application of psychological theory to pronunciation problems in second language learning. Modern Language Journal 36: 111-114.

Scovel, T. 1969. Foreign accents, language acquisition and cerebral dominance. Language Learning 19: 245-263.

Sobkowiak, W. 1996. English Phonetics for Poles. Poznań: Bene Nati.

Stott, J. 2017. Between Two Worlds: the Challenge of Preaching Today. Grand Rapids, Michigan: Eerdmans Publishing Company.

Strother, J. B. 1999. Communication failures lead to airline disasters. IPCC 99: Communication jazz: Improvising the new international communication culture: Proceedings. Paper presented at the 1999 IEEE International Professional Communication Conference, New Orleans, LA, September 7-10, 29-34. Piscataway, NJ: IEEE.

Szpyra-Kozłowska, J. 2013. On the irrelevance of sounds and prosody in foreign-accented speech. In: E. Waniek-Klimczak \& L. Shockey (eds.), Teaching and Researching English Accents in Native and Non-native Speakers, 15-29. Berlin: Springer Berlin Heidelberg.

Thompson, I. 1991. Foreign accents revisited: The English pronunciation of Russian emigrants. Language Learning 41 (2): 177-204.

Trudgill, P. \& Hannah, J. 1994. International English. A Guide to Varieties of Standard English. Bristol: J. W. Arrowsmith Ltd.

Walley, A. 2007. Speech learning, lexical reorganization, and the development of word recognition by native and non-native English speakers. In: O.-S. Bohn \& M. Munro (eds.), Language Experience in Second Language Learning, 315-330. Amsterdam: John Benjamins Publishing.

Williams, F. 1970. Language, attitude and social change. In: F. Williams (ed.), Language and Poverty: Perspectives on a Theme, 380-399. Chicago, IL: Markham.

Woods, P. 2006. The hedgehog and the fox; Approaches to English for peacekeeping. In: J. Edge (ed.), (Re)locating TESOL in An Age of Empire, 208-226. New York: Polgrave Macmillan.

Wright, R. 2004. Factors of lexical competition in vowel articulation. In: J. Local, R. Ogden \& R. Temple (eds.), Phonetic Interpretation: Papers in Laboratory Phonology VI, 75-87. Cambridge: Cambridge University Press.

\section{links to the talks:}

Fr. P. Glas

"The Strategy of the Devil in our lives" https: / / www.youtube.com/watch?v=u3Z4CNERkfw "Spiritual warfare" https: / / www.youtube.com/watch?v=jI4CqFAymDw\&t=1619s 
"Opening doorways to the demonic activity" https: / / www.youtube.com/watch?v=n61ZfLE_ XyQ\& $=774 \mathrm{~s}$

“The evil spirits in action" https: / / www.youtube.com/watch?v=QVIIbVawzXM

"The distraction power of the Jezebel spirit" https: / / www.youtube.com/watch?v=MxaEn7X1$E c \& t=2132 s$

Dalai Lama https: / / www.youtube.com/watch?v=HbC-TXNGK1M

***

Agnieszka Bryła-Cruz is an Adjunct Professor at Maria Curie-Skłodowska University in Lublin, Poland. Her main research interests concern the role of linguistic and socio-linguistic factors in Second Language Acquisition, particularly pronunciation, and the perception of non-native accents by English native speakers. More recently, she has studied the role of phonetics in listening comprehension in a series of empirical studies. 